ScIDice

\section{A Questionnaire Based Survey On Fear and Anxiety Levels of Patient Before and After Endodontic} Treatment

Research Article

Immadi Laxmi Sujith Kumar ${ }^{1}$, Sindhu Ramesh ${ }^{2 *}$

${ }^{1}$ Department of Conservative Dentistry and Endodontics, Saveetha Dental College, Saveetha Institute of Medical and Technical Sciences, Saveetha University, Chennai- 600077, India.

${ }^{2}$ Professor, Department of Conservative Dentistry and Endodontics, Saveetha Dental College, Saveetha Institute of Medical and Technical Sciences, Saveetha University, Chennai- 600077, India.

\title{
Abstract
}

Dental anxiety refers to a patient's specific reaction toward stress associated with dental treatment in which the stimulus is unknown, vague, or not present at the moment. It is widespread problems that persist despite the technological advances that have made dentistry less painful and uncomfortable. The present cross-sectional study was conducted in the Department of Conservative Dentistry and Endodontics, Saveetha Dental College from November 2019 to December 2019. A simple random sampling technique was used for the study and a sample size of 300 adult patients aged 18-40 years attending Outpatient were selected. The survey was done based on two sets of questionnaires and the patients were asked to complete the questionnaires before and after endodontic treatment. The present study concluded that female subjects were ranked highly and severely anxious with modified dental anxiety scale before root canal treatment. It was also reported that female subjects after root canal treatment were also ranked highly anxious.

Keywords: Corah Dental Anxiety Scale; Dental Anxiety; Dental Fear; Modified Dental Anxiety Scale; Root Canal Treatment.

\section{Introduction}

Dental anxiety is characterized as a patient's particular response towards stress identified with the dental treatment during which the upgrade is obscure, dubious, or not present at that moment [1-4]. It's a far reaching issue that endures in spite of the logical advances that made dentistry less painful [5]. Depending on the populace and the estimation method, $2.5-20 \%$ individuals endure high dental anxiety $[6,7]$. It has been assessed that around $80 \%$ of the Americans were positioned profoundly on edge in regards to dental treatment and $5-14 \%$ of them were positioned seriously anxious $[8,9]$. Research considers revealed that dental anxiety is progressively normal in women [10-12]. Recognition of a patient's dental nervousness helps in arrangement of the crucial data for a dental specialist in taking care of business a patient-dental specialist relationship [13]. Dental anxiety and fear seem to shift in sync with sort of treatment [14]. Periodontal or endodontic medicines have been appeared to cause more significant levels of nervous- ness than remedial or prophylactic treatments [15-18]. Patients' pre-treatment choices and post treatment fulfilment might be emphatically impacted by social, mental, and conduct viewpoints including information, convictions, perspectives, inclinations and behaviours [19-22]. Patients may know about endodontic pathology yet are probably going to be exceptionally sharpened to treatment-related dread, uneasiness and torment and are increasingly worried about expense, and whether the treated tooth satisfies their practical and stylish expectations [23]. There is no uncertainty that root canal treatment can increment physiological and mental feelings of anxiety. Patients who had undergone root canal treatment experienced fair to very much fear of pain, or 3-4 on a 5-point scale. Agony experienced during root canal treatment is related with the degree of foreseen nervousness level. Half of the patients detailed no adjustment in dread level after root canal treatment, however $44 \%$ revealed less fear after root canal treatment, and just $6 \%$ announced more dread after root canal treatment. Past encounters of root canal treatment will in gen-

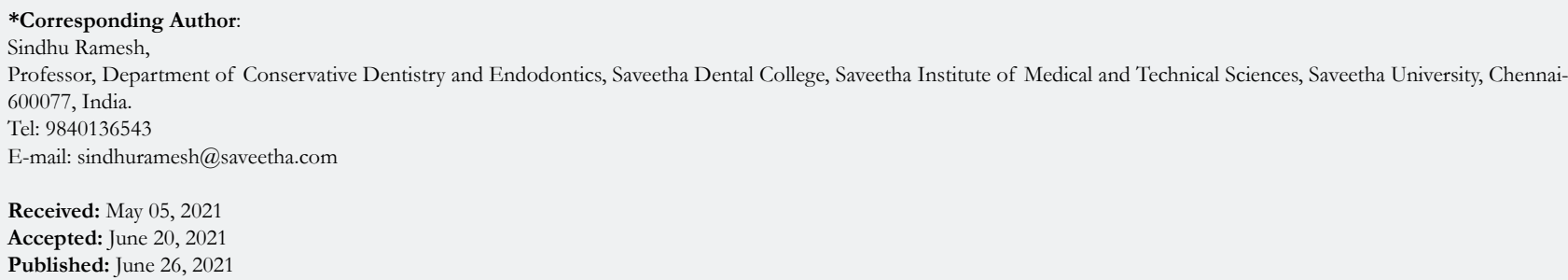

Copyright: Sindhu Ramesh ${ }^{2021}$. This is an open-access article distributed under the terms of the Creative Commons Attribution License, which permits unrestricted use, distribution and reproduction in any medium, provided the original author and source are credited. 
eral abatement tension; experience may balance negative gossip. Strangely, negative noise builds entry treatment related nervousness, yet past negative section treatment encounters don't increase anxiety [24]. Females will in general experience more root canal treatment related tension and envision more agony than men [25]. Younger grown-ups foresee and experience higher torment levels and they may likewise encounter more anxiety [26]. Results of studies looking at dental uneasiness level and sexual orientation are clashing. Bergdahl and Hakeberg, et al. 2003 detailed more significant levels of dental tension among females, yet Sari, et al. 2005 neglected to locate any such contrast between genders [2224]. Prior to treatment, dental specialists ought to have the option to identify a patient's degree of tension and dread so they can utilize suitable administration alternatives. Accordingly, a few scales have been produced for this expectation. Modified Dental Anxiety Scale is utilized in this survey.

Previously our team has a rich experience in working on various research projects across multiple disciplines [27-41]. Now the growing trend in this area motivated us to pursue this project.

The aim of the present survey is to evaluate fear and anxiety levels of patients before and after Endodontic treatment.

\section{Materials And Methods}

The present cross-sectional study was conducted in the Department of Conservative Dentistry and Endodontics, Saveetha Dental College from November 2019 to December 2019. All the respondents were provided to sign a detailed informed consent form. The Survey done was based on two sets of questionnaires and the patients were asked to complete the questionnaires before and after endodontic treatment. The first questionnaire was the Modified Dental anxiety scale which consisted of five questions. Respondents rate each item on a five point scale that ranges from not anxious to extremely anxious, in ascending order. Each question carries a possible maximum score of five, and the total score is a sum of all five questions, ranging between 5 to 25 . Cut off is 19 or above which indicates a highly dentally anxious patient, possibly dental phobic. The second questionnaire consisted of eleven questions, which were asked after treatment including questions on tapping on a sore tooth, multiple X-rays taken, anesthesia, drilling of tooth, sensations of files, appointments of root canal treatments and lengths of root canal treatment which were asked after treatment. Both the questionnaires were meant to analyze the response of the patient's anxiety and fear towards endodontic treatment.

\section{Ethical Approval}

Ethical permission and approval for the project was obtained from the institutional review board of Saveetha Institute Of Medical And Technical Sciences, Chennai, India on date 25/08/2018 (SRB/SD/MDS12/129 ODS/19).

\section{Eligibility Criteria}

Patients aged 18-40 years attending Outpatient Department of Conservative dentistry and endodontics in Saveetha Dental College And Hospital were selected.

\section{Sample Size}

The sample size was calculated by taking this prevalence rate and computed using $\mathrm{G}^{*}$ Power at $95 \%$ confidence interval and $\alpha=5 \%$ and sample size of 300 was obtained. Patients aged less than 18 years and above 40 years were excluded from the study.

\section{Data Collection}

This cross sectional survey was conducted during November 2019 to December 2019. The questionnaire was shared via physical forms and responses were obtained from 300 patients. The data form the questionnaire was compiled and statistical analysis was done.

\section{Statistical Analysis}

Data was analyzed by using Statistical Package for Social Sciences software version 20.0 (SPSS Inc., Chicago, IL, USA) for frequency and percentages of dental anxiety before and after endodontic treatment. Chi- squared test was done to compare fear levels in relation to gender.

\section{Results}

Frequency of age and gender distribution of patients who took part in the survey, which shows that male participants are higher $(57.0 \%)$ than female participants $(43.0 \%)$ and participants under the age group of $36-40$ years are higher in number $(34.0 \%)$.(Table 1) $3(15.7 \%)$ males and $16(84.3 \%)$ females were found to be extremely anxious according to the Modified Dental Anxiety Scale before endodontic treatment. (Table 2) Chi square test for comparison of fear in relation to gender after endodontic treatment was done and all the questions showed statistically significant $\mathrm{p}$ value $<0.05$ (Table 3). The association between gender and re-

Table 1. Frequency of age and gender distribution of patients who took part in the survey, which shows that male participants are higher $(57.0 \%)$ than female participants $(43.0 \%)$ and participants under the age group of 36-40 years are higher in number(34.0\%).

\begin{tabular}{|c|c|c|c|}
\hline Demographic variables & Categories & No. of Respondents & Percentage \% \\
\hline \multirow{3}{*}{ Gender } & Female & 129 & 43 \\
\cline { 2 - 4 } & Male & 171 & 57 \\
\hline \multirow{3}{*}{ Age (years) } & $18-25$ years & 66 & 22 \\
\cline { 2 - 4 } & $26-30$ years & 84 & 28 \\
\cline { 2 - 4 } & $31-35$ years & 48 & 16 \\
\cline { 2 - 4 } & $36-40$ years & 102 & 34 \\
\hline
\end{tabular}


Table 2. Shows Modified Dental Anxiety Scale(MDAS) before endodontic treatment.

\begin{tabular}{|c|c|c|c|}
\hline Modified dental anxiety scale (MDAS) & Male & Female & Total \\
\hline Not anxious(0-5) & $60(58.8 \%)$ & $42(41.2 \%)$ & $102(100 \%)$ \\
\hline Slightly anxious(6-10) & $32(37.2 \%)$ & $54(62.8 \%)$ & $86(100 \%)$ \\
\hline Fairly anxious(11-14) & $22(35.4 \%)$ & $40(64.6 \%)$ & $62(100 \%)$ \\
\hline Very anxious(15-18) & $10(32.2 \%)$ & $21(67.8 \%)$ & $31(100 \%)$ \\
\hline Extremely anxious(19-25) & $3(15.7 \%)$ & $16(84.3 \%)$ & $19(100 \%)$ \\
\hline
\end{tabular}

Table 3. Shows Correlation of Fear with Gender after Endodontic Treatment.

\begin{tabular}{|c|c|c|c|c|c|c|}
\hline \multirow{2}{*}{ Questions } & \multirow{2}{*}{ Variables } & \multicolumn{2}{|c|}{ Gender } & \multirow{2}{*}{ Total } & \multirow{2}{*}{$\begin{array}{l}\text { Chi Square } \\
\text { value }\end{array}$} & \multirow{2}{*}{$\mathrm{p}$ value } \\
\hline & & Male & Female & & & \\
\hline \multirow{6}{*}{$\begin{array}{l}\text { Do you mind the } \\
\text { dentist tapping or } \\
\text { pushing on the sore } \\
\text { tooth? }\end{array}$} & Not at all & 53 & 9 & 62 & \multirow{6}{*}{53.17} & \multirow{6}{*}{0.000} \\
\hline & A little & 66 & 43 & 109 & & \\
\hline & Somewhat & 25 & 47 & 72 & & \\
\hline & Much & 6 & 16 & 22 & & \\
\hline & Very much & 4 & 10 & 14 & & \\
\hline & Never experienced & 17 & 4 & 21 & & \\
\hline \multirow{6}{*}{$\begin{array}{c}\text { Do you mind the use } \\
\text { of an electric pulp } \\
\text { tester? }\end{array}$} & Not at all & 56 & 8 & 64 & \multirow{6}{*}{56.62} & \multirow{6}{*}{0.000} \\
\hline & A little & 64 & 45 & 109 & & \\
\hline & Somewhat & 24 & 46 & 70 & & \\
\hline & Much & 6 & 16 & 22 & & \\
\hline & Very much & 4 & 10 & 14 & & \\
\hline & Never experienced & 17 & 4 & 21 & & \\
\hline \multirow{5}{*}{$\begin{array}{l}\text { Do you mind having } \\
\text { multiple x-ray taken } \\
\text { of your tooth? }\end{array}$} & Not at all & 37 & 3 & 40 & \multirow{5}{*}{41.531} & \multirow{5}{*}{0.000} \\
\hline & A little & 72 & 37 & 109 & & \\
\hline & Somewhat & 47 & 59 & 106 & & \\
\hline & Much & 13 & 27 & 40 & & \\
\hline & Very much & 2 & 3 & 5 & & \\
\hline \multirow{5}{*}{$\begin{array}{c}\text { Do you mind when } \\
\text { an } \mathrm{x} \text {-ray receptor was } \\
\text { placed in your mouth? }\end{array}$} & Not at all & 22 & 0 & 22 & & \\
\hline & A little & 64 & 25 & 89 & & \\
\hline & Somewhat & 54 & 46 & 100 & 44.545 & 0.000 \\
\hline & Much & 25 & 39 & 64 & & \\
\hline & Very much & 6 & 19 & 25 & & \\
\hline & Not at all & 15 & 0 & 15 & & \\
\hline Do you mind when & A little & 77 & 22 & 99 & & \\
\hline a metal rubber dam & Somewhat & 49 & 47 & 96 & 53.371 & 0.000 \\
\hline your tooth? & Much & 23 & 35 & 58 & & \\
\hline & Very much & 7 & 25 & 32 & & \\
\hline & Not at all & 15 & 0 & 15 & & \\
\hline & A little & 78 & 22 & 78 & & \\
\hline Do you mind the use & Somewhat & 51 & 52 & 51 & 53.933 & 0.000 \\
\hline & Much & 21 & 34 & 21 & & \\
\hline & Very much & 6 & 21 & 6 & & \\
\hline & Not at all & 66 & 2 & 68 & & \\
\hline Do you mind get- & A little & 51 & 30 & 81 & & \\
\hline ting an injection for & Somewhat & 34 & 27 & 61 & 92.199 & 0.000 \\
\hline anaesthesia? & Much & 12 & 27 & 39 & & \\
\hline & Very much & 8 & 43 & 51 & & \\
\hline & Not at all & 71 & 11 & 82 & & \\
\hline & A little & 70 & 59 & 129 & & \\
\hline Do you mind the drill & Somewhat & 26 & 41 & 67 & 52.345 & 0 \\
\hline & Much & 3 & 15 & 18 & & \\
\hline & Very much & 1 & 3 & 4 & & \\
\hline & Not at all & 82 & 18 & 100 & & \\
\hline Do you mind the & A little & 71 & 68 & 139 & & \\
\hline sensation of the root & Somewhat & 16 & 36 & 52 & 46.753 & 0.000 \\
\hline canal files? & Much & 2 & 6 & 8 & & \\
\hline & Very much & 0 & 1 & 1 & & \\
\hline & Not at all & 18 & 3 & 21 & & \\
\hline Do you mind the & A little & 69 & 21 & 90 & & \\
\hline length of appoint- & Somewhat & 66 & 51 & 117 & 51.963 & 0.000 \\
\hline root canal therapy? & Much & 16 & 43 & 59 & & \\
\hline & Very much & 2 & 11 & 13 & & \\
\hline & Not at all & 80 & 10 & 90 & & \\
\hline All things considered, & A little & 56 & 53 & 109 & & \\
\hline are you fearful of & Somewhat & 29 & 40 & 69 & 64.192 & 0.000 \\
\hline $\begin{array}{l}\text { work? } \\
\text { worling loot calla }\end{array}$ & Much & 4 & 16 & 20 & & \\
\hline & Very much & 2 & 10 & 12 & & \\
\hline
\end{tabular}


sponses for have you ever cancelled or missed an appointment for root canal therapy because you were apprehensive or fear is shown in (Chart 1). The association between gender and responses for would you have root canal therapy again to save one of your teeth is shown in (Chart 2).

\section{Discussion}

Our institution is passionate about high quality evidence based research and has excelled in various fields [42-52].

Dental anxiety, fear and phobia are known to extremely influence patients behaviors and felt experiences [53-56]. Fearful patients are more likely to experience and remember more pain $[53,55]$ and they also tend to avoid necessary treatment perpetuating a vicious cycle of dental fear and avoidance $[53,56,57]$. The present study reported that $16(84.3 \%)$ of the females and $3(15.7 \%)$ of males were extremely anxious about root canal treatment. LeClaire,et al. 1988 reported that 1(5.6\%) of subjects who missed or got cancelled the appointments because of fear [19]. Scott, et al. 1984 in his study reported that high and low dentally anxious subjects did not differ significantly in the number of dental appointments cancelled [58]. Even though root canal therapy can usually be performed with a minimum of discomfort, many patients express apprehension concerning therapy before the start of treatment [19]. The present study reported that 86 were found to be slightly anxious, 62 were fairly anxious and 19 were found to be extremely anxious. Le Claire, et al. 1988 in his study reported $18(22 \%)$ subjects were found to be highly anxious [19]. Physiologic stress peaks early in a RCT appointment, around the time of local anesthesia delivery and initial instrumentation [16, 59]. The present study reported that subjects were least anxious during initial instrumentation and only females were found to be anxious.

Hamedy R, et al. 2013 reported that patients ranked the following from least to most anxiety producing as: electric pulp testing, rubber dam, appointment length, multiple radiographs, rubber dam clamp placement, X-ray film placement, access opening, percussing a sore tooth, sensing files, local anesthesia injection [60]. LeClaire, et al. 1988 ranked use of the electric pulp tester, rubber dam, length of appointments among the least unpleasant aspects and $\mathrm{X}$ ray film placement, access opening of intermediate concern [19].

Ali S, et al. 2015 reported that $59.5 \%$ of males and $48.4 \%$ of females showed fear of injection needle followed by $29.7 \%$ of males and $29.7 \%$ of females reported fear from vibration of the drill, $21.6 \%$ of males and $28.1 \%$ of females had fear from rubber dam placement, $16.2 \%$ of males and $10.9 \%$ of the females reported fear from X-rays [61]. The present study reported that $36 \%$ of females and $22.7 \%$ of males were highly anxious when $\mathrm{x}$-ray film was placed in their mouth. $26.8 \%$ of males were found to be highly anxious when multiple $x$-rays were taken. $25.2 \%$ of females and $20.6 \%$ of males were highly anxious about the length

Chart 1. Bar chart showing the association between gender and responses for have you ever cancelled or missed an appointment for root canal therapy because you were apprehensive or fear.X axis represents the question variables and $y$ axis represents the number of responses from the participants. The association between Male(green) and Female(blue) among the different variables was found to be statistically significant with a Chi square value of 39.894 and $p$ value of $0.000(p<0.05)$.

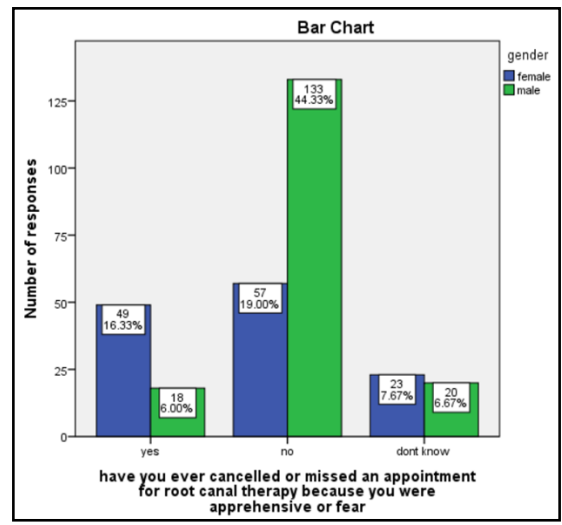

Chart 2. Bar chart showing the association between gender and responses for would you have root canal therapy again to save one of your teeth. $\mathbf{X}$ axis represents the question variables and $\mathbf{y}$ axis represents the number of responses from the participants. The association between Male(green) and Female(blue) among the different variables was found to be statistically significant with a Chi square value of 25.390 and $p$ value of $0.000(p<0.05)$.

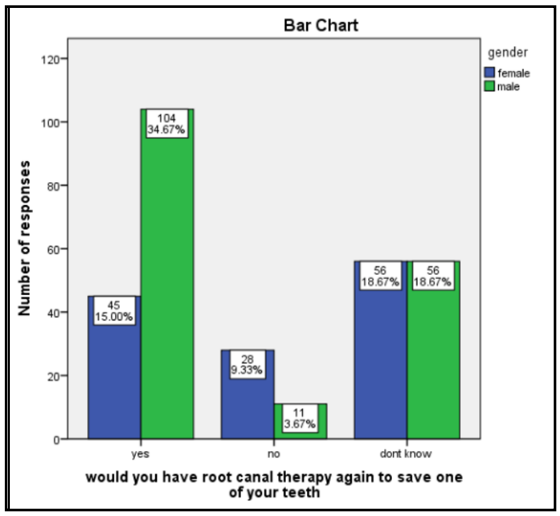


of appointments required during root canal treatment.

Thirty eight $(38 \%)$ of the females and $20(20.6 \%)$ of the males reported fear towards tapping and pushing on a tooth. LeClaire, et al. 1988 in his study also ranked subjects highly anxious about tapping or pushing on a sore tooth and the most unpleasant aspect of root canal therapy [19]. Needle fear, in particular, is a major issue given that the delivery of local anaesthesia via injection is the central plank of pain relief techniques in dentistry [62]. Honkala S, et al. 2014 reported that use of drill and injection were the highest anxiety arousing dental procedure [63].

Females generally had a greater phobia of dental procedures than their males. One reason for this trend could be that males tend to hide their fears due to their orthodox gender role [64]. In addition, it has been reported that, in general, females are more reactive to a specific stimulus (like a needle prick) than males, which could account for the higher anxiety levels reported by females in various studies [65, 66]. Kanegane, et al. 2009 reported no relation between gender and dental anxiety [67]. Masoud, et al. 2015 in his study reported that female patients demonstrate higher levels of dental anxiety than males [68]. Similar results were reported by many authors that dental anxiety is more common in women $[2,6,69,70,71]$. The present study also reported higher levels of dental anxiety in women. This difference may be explained by women being more able to express their feelings of fear. In addition, physiological conditions such as social phobia panic, depression, stress, and fear are more common in females and dental anxiety may be associated with such emotions [9]. drill and injection were the highest anxiety arousing dental procedure. Ali S, et al. 2015 also reported the most feared dental procedure was fear of an injection/ needle [61].

\section{Study Limitations}

The limitation of the present study includes small sample size and that data collection was done from only one Dental College. Another was that the patients included in the study were from the same locality and this affected the outcome of the study. Pretreatment anxiety levels are assessed by Modified Dental Anxiety Scale but there is until now no anxiety scale developed that will assess post treatment anxiety level.

\section{Conclusion}

The present study concluded that female subjects were ranked highly and severely anxious with modified dental anxiety scale before root canal treatment. It was also reported that female subjects after root canal treatment were also ranked highly anxious.

\section{Clinical Significance}

Dentists need to be trained in anxiety management and communication techniques, this consideration will help in development of specialist postgraduates courses for dentists in management of dental anxiety. Such initiatives allow interested dentists to gain more confidence, more experience and skills in this specialised field of dentistry.

\section{Acknowledgement}

With Sincere gratitude,we acknowledge the staff members of the department of Conservative Dentistry and Endodontics, Saveetha Dental College and study participants for their extended support towards the completion of research.

\section{References}

[1]. Jaakkola S, Rautava P, Alanen P, Aromaa M, Pienihäkkinen K, Räihä H, Vahlberg T, Mattila M-L, Sillanpää M (2009) Dental Fear: One Single Clinical Question for Measurement. The Open Dentistry Journal 3:161-166

[2]. Humphris GM, Dyer TA, Robinson PG (2009) The modified dental anxiety scale: UK general public population norms in 2008 with further psychometrics and effects of age. BMC Oral Health 9:20

[3]. Locker D (2003) Psychosocial consequences of dental fear and anxiety. Community Dentistry and Oral Epidemiology 31:144-151

[4]. Hagglin C, Hakeberg M, Ahlqwist M, Sullivan M, Berggren U (2000) Factors associated with dental anxiety and attendance in middle-aged and elderly women. Community Dentistry and Oral Epidemiology 28:451-460

[5]. Skaret E, Raadal M, Kvale G, Berg E (2000) Factors related to missed and cancelled dental appointments among adolescents in Norway. European Journal of Oral Sciences 108:175-183

[6]. Taani DSMQ, Quteish DS (2001) Dental fear among a young adult Saudian population. International Dental Journal 51:62-66

[7]. Vassend O (1993) Anxiety, pain and discomfort associated with dental treatment. Behaviour Research and Therapy 31:659-666

[8]. Scott DS, Hirschman R (1982) Psychological aspects of dental anxiety in adults. J Am Dent Assoc 104:27-31

[9]. Arslan S, Tarım Ertaş E, Ülker M (2011) The relationship between dental fear and sociodemographic variables. Erciyes Medical Journal 33:295-300

[10]. Akarslan ZZ, Erten H, Uzun O, Iseri E, Topuz O (2010) Relationship between trait anxiety, dental anxiety and DMFT indexes of Turkish patients attending a dental school clinic. Eastern Mediterranean Health Journal $16: 558-562$

[11]. Dobros K, Hajto-Bryk J, Wnek A, Zarzecka J, Rzepka D (2014) The level of dental anxiety and dental status in adult patients. J Int Oral Health 6:11-14

[12]. Stabholz A, Peretz B (1999) Dental Anxiety Among Patients Prior to Different Dental Treatments. Int Dent J.

[13]. Wong M, Reed Lytle W (1991) A comparison of anxiety levels associated with root canal therapy and oral surgery treatment. Journal of Endodontics $17: 461-465$

[14]. Vaughn LM, Jacquez F, Bakar RC (2009) Cultural health attributions, beliefs, and practices: Effects on healthcare and medical education. The Open Medical Education Journal 2:

[15]. Edwards RR, Doleys DM, Lowery D, Fillingim RB (2003) Pain Tolerance as a Predictor of Outcome Following Multidisciplinary Treatment for Chronic Pain: Differential Effects as a Function of Sex. Pain.

[16]. Georgelin-Gurgel M, Diemer F, Nicolas E, Hennequin M (2009) Surgical and Nonsurgical Endodontic Treatment-Induced Stress. J Endod.

[17]. Armfield JM, Pohjola V, Joukamaa M, Mattila AK, Suominen AL, Lahti SM (2011) Exploring the Associations Between Somatization and Dental Fear and Dental Visiting. Eur J Oral Sci.

[18]. van Wijk AJ, Hoogstraten J (2006) Reducing Fear of Pain Associated With Endodontic Therapy. Int Endod J.

[19]. LeClaire AJ, Skidmore AE, Griffin JA, Balaban FS (1988) Endodontic Fear Survey. J Endod.

[20]. Peretz B, Moshonov J (1998) Dental Anxiety Among Patients Undergoing Endodontic Treatment. J Endod.

[21]. Watkins CA, Logan HL, Kirchner HL (2002) Anticipated and Experienced Pain Associated With Endodontic Therapy. J Am Dent Assoc.

[22]. Bergdahl M, Bergdahl J (2003) Temperament and Character Personality Dimensions in Patients With Dental Anxiety. Eur J Oral Sci.

[23]. Hakeberg M, Berggren U, Carlsson SG (1992) Prevalence of Dental Anxiety in an Adult Population in a Major Urban Area in Sweden. Community Dent Oral Epidemiol.

[24]. Sari Z, Uysal T, Karaman AI, Sargin N, Üre Ö (2005) Does orthodontic treatment affect patients' and parents' anxiety levels? European Journal of Orthodontics 27:155-159

[25]. Treating fearful dental patients : a patient management handbook (Book, 1985)

[26]. Treasure E, Kelly M, Nuttall N, Nunn J, Bradnock G, White D (2001) Factors associated with oral health: a multivariate analysis of results from the 1998 Adult Dental Health survey. British Dental Journal 190:60-68

[27]. Govindaraju L, Gurunathan D (2017) Effectiveness of Chewable Tooth Brush in Children-A Prospective Clinical Study. J Clin Diagn Res 11:ZC31ZC34 
[28]. Christabel A, Anantanarayanan P, Subash P, Soh CL, Ramanathan M, Muthusekhar MR, Narayanan V (2016) Comparison of pterygomaxillary dysjunction with tuberosity separation in isolated Le Fort I osteotomies: a prospective, multi-centre, triple-blind, randomized controlled trial. Int J Oral Maxillofac Surg 45:180-185

[29]. Soh CL, Narayanan V (2013) Quality of life assessment in patients with dentofacial deformity undergoing orthognathic surgery--a systematic review. Int J Oral Maxillofac Surg 42:974-980

[30]. Mehta M, Deeksha, Tewari D, et al (2019) Oligonucleotide therapy: An emerging focus area for drug delivery in chronic inflammatory respiratory diseases. Chem Biol Interact 308:206-215

[31]. Ezhilarasan D, Apoorva VS, Ashok Vardhan N (2019) Syzygium cumini extract induced reactive oxygen species-mediated apoptosis in human oral squamous carcinoma cells. J Oral Pathol Med 48:115-121

[32]. Campeau PM, Kasperaviciute D, Lu JT, et al (2014) The genetic basis of DOORS syndrome: an exome-sequencing study. Lancet Neurol 13:44-58

[33]. Kumar S, S S (2016) Knowledge and awareness regarding antibiotic prophylaxis for infective endocarditis among undergraduate dental students. Asian J Pharm Clin Res 154

[34]. Christabel SL (2015) Prevalence of type of Frenal Attachment and morphology of frenum in children, Chennai, Tamil Nadu. World J Dent 6:203-207

[35]. Kumar S, Rahman R (2017) Knowledge, awareness, and practices regarding biomedical waste management among undergraduate dental students. Asian J Pharm Clin Res 10:341

[36]. Sridharan G, Ramani P, Patankar S (2017) Serum metabolomics in oral leukoplakia and oral squamous cell carcinoma. J Cancer Res Ther 13:556-561

[37]. Ramesh A, Varghese SS, Doraiswamy JN, Malaiappan S (2016) Herbs as an antioxidant arsenal for periodontal diseases. J Intercult Ethnopharmacol 5:92-96

[38]. Thamaraiselvan M, Elavarasu S, Thangakumaran S, Gadagi JS, Arthie T (2015) Comparative clinical evaluation of coronally advanced flap with or without platelet rich fibrin membrane in the treatment of isolated gingival recession. J Indian Soc Periodontol 19:66-71

[39]. Thangaraj SV, Shyamsundar V, Krishnamurthy A, Ramani P, Ganesan K, Muthuswami M, Ramshankar V (2016) Molecular Portrait of Oral Tongue Squamous Cell Carcinoma Shown by Integrative Meta-Analysis of Expression Profiles with Validations. PLoS One 11:e0156582

[40]. Ponnulakshmi R, Shyamaladevi B, Vijayalakshmi P, Selvaraj J (2019) In silico and in vivo analysis to identify the antidiabetic activity of beta sitosterol in adipose tissue of high fat diet and sucrose induced type- 2 diabetic experimental rats. Toxicol Mech Methods 29:276-290

[41]. (2018) Fluoride, fluoridated toothpaste efficacy and its safety in children review. Int J Pharm Res.

[42]. Vijayashree Priyadharsini J (2019) In silico validation of the non-antibiotic drugs acetaminophen and ibuprofen as antibacterial agents against red complex pathogens. J Periodontol 90:1441-1448.

[43]. Pc J, Marimuthu T, Devadoss P (2018) Prevalence and measurement of anterior loop of the mandibular canal using CBCT: A cross sectional study. Clin. Implant Dent. Relat. Res.

[44]. Ramesh A, Varghese S, Jayakumar ND, Malaiappan S (2018) Comparative estimation of sulfiredoxin levels between chronic periodontitis and healthy patients - A case-control study. J Periodontol 89:1241-1248

[45]. Ramadurai N, Gurunathan D, Samuel AV, Subramanian E, Rodrigues SJL (2019) Effectiveness of $2 \%$ Articaine as an anesthetic agent in children: randomized controlled trial. Clin Oral Investig 23:3543-3550

[46]. Sridharan G, Ramani P, Patankar S, Vijayaraghavan R (2019) Evaluation of salivary metabolomics in oral leukoplakia and oral squamous cell carcinoma. J Oral Pathol Med 48:299-306

[47]. Ezhilarasan D, Apoorva VS, Ashok Vardhan N (2019) Syzygium cumini extract induced reactive oxygen species-mediated apoptosis in human oral squamous carcinoma cells. J Oral Pathol Med 48:115-121

[48]. Mathew MG, Samuel SR, Soni AJ, Roopa KB (2020) Evaluation of adhesion of Streptococcus mutans, plaque accumulation on zirconia and stainless steel crowns, and surrounding gingival inflammation in primary molars:
Randomized controlled trial. Clin Oral Investig 1-6

[49]. Samuel SR (2021) Can 5-year-olds sensibly self-report the impact of developmental enamel defects on their quality of life? Int J Paediatr Dent 31:285-286

[50]. R H, Hannah R, Ramani P, Ramanathan A, R JM, Gheena S, Ramasubramanian A, Monika K (2020) CYP2 C9 polymorphism among patients with oral squamous cell carcinoma and its role in altering the metabolism of benzo[a]pyrene. Oral Surgery, Oral Medicine, Oral Pathology and Oral Radiology 130:306-312

[51]. Chandrasekar R, Chandrasekhar S, Sundari KKS, Ravi P (2020) Development and validation of a formula for objective assessment of cervical vertebral bone age. Prog Orthod 21:38

[52]. Vijayashree Priyadharsini J, Smiline Girija AS, Paramasivam A (2018) In silico analysis of virulence genes in an emerging dental pathogen A. baumannii and related species. Arch Oral Biol 94:93-98

[53]. Klages U, Ulusoy O, Kianifard S, Wehrbein H (2004) Dental Trait Anxiety and Pain Sensitivity as Predictors of Expected and Experienced Pain in Stressful Dental Procedures. Eur J Oral Sci.

[54]. Pohjola V, Lahti S, Tolvanen M, Hausen H (2008) Dental Fear and Oral Health Habits Among Adults in Finland. Acta Odontol Scand.

[55]. Pohjola V, Lahti S, Suominen-Taipale L, Hausen H (2009) Dental Fear and Subjective Oral Impacts Among Adults in Finland. Eur J Oral Sci.

[56]. Armfield JM (2013) What Goes Around Comes Around: Revisiting the Hypothesized Vicious Cycle of Dental Fear and Avoidance. Community Dent Oral Epidemiol.

[57]. Sharif MO (2010) Dental Anxiety: Detection and Management. J Appl Oral Sci.

[58]. Scott DS, Hirschman R, Schroder K (1984) Historical Antecedents of Dental Anxiety. J Am Dent Assoc.

[59]. Morse DR, Chow E (1993) The Effect of the Relaxodont Brain Wave Synchronizer on Endodontic Anxiety: Evaluation by Galvanic Skin Resistance, Pulse Rate, Physical Reactions, and Questionnaire Responses. Int. J. Psychosom. 40:

[60]. Hamedy R, Shakiba B, Fayazi S, Pak JG, White SN (2013) Patient-centered Endodontic Outcomes: A Narrative Review. Iran. Endod. J. 8:

[61]. (2015) Self-reported anxiety of dental procedures among dental students and its relation to gender and level of education. Journal of Taibah University Medical Sciences 10:449-453

[62]. Malamed S (2009) What's New in Local Anaesthesia? SAAD Dig. 25:

[63]. Honkala S, Al-Yahya H, Honkala E, Freeman R, Humphris G (2014) Validating a Measure of the Prevalence of Dental Anxiety as Applied to Kuwaiti Adolescents. Community Dent. Health 31:

[64]. Farooq I, Ali S(2015) A cross sectional study of gender differences in dental anxiety prevailing in the students of a Pakistani dental college. The Saudi Journal for Dental Research 6:21-25

[65]. Newton T, Asimakopoulou K, Daly B, Scambler S, Scott S (2012) The Management of Dental Anxiety: Time for a Sense of Proportion? Br Dent J.

[66]. Armfield JM (2010) How Do We Measure Dental Fear and What Are We Measuring Anyway? Oral Health Prev. Dent. 8:

[67]. Kanegane K, Penha SS, Munhoz CD, Rocha RG (2009) Dental Anxiety and Salivary Cortisol Levels Before Urgent Dental Care. J Oral Sci.

[68]. Saatchi M, Abtahi M, Mohammadi G, Mirdamadi M, Binandeh ES (2015) The Prevalence of Dental Anxiety and Fear in Patients Referred to Isfahan Dental School, Iran. Dent. Res. J. 12:

[69]. Erten H, Akarslan ZZ, Bodrumlu E (2006) Dental Fear and Anxiety Levels of Patients Attending a Dental Clinic. Quintessence Int. 37:

[70]. Nascimento DL do, Araújo AC da S, Gusmâo ES, Cimôes R (2011) Anxiety and fear of dental treatment among users of public health services. Oral Health Prev. Dent. 9:

[71]. Peretz B, Efrat J (2000) Dental Anxiety Among Young Adolescent Patients in Israel. Int J Paediatr Dent. 